\title{
The Role of Business Incubators in the Economic Development and Creativity in Jordanian Universities: Evidence from Mutah University
}

\author{
Shadi Arshid Muslim Saraireh \\ Associate Professor, Faculty of Business, \\ Amman University College; \\ Balqa Applied University, \\ P.O. B. 206, Salt 19117, Jordan
}

DOI: https://doi.org/10.36941/ajis-2021-0023

\section{Abstract}

The study aimed to investigate the role of business incubators in economic development and creativity in Jordanian universities. The study population included Mutah University students who were enrolled in the entrepreneurship program during the academic year 2019-2020. A random sample of 208 male and female students voluntarily participated in the study. A questionnaire that examined four dimensions was used to collect data. These dimensions included: the training and consulting dimension, the technical support and performance evaluation dimension, the administrative and office services dimension, and the financial support dimension. The validity and reliability of these dimensions were also confirmed. The results revealed the important role of business incubators in economic development and creativity in Jordanian universities. They also showed that the training and consulting dimension ranked higher than the other dimensions. The following dimension was the administrative and office services. The technical support and performance evaluation dimension came in third place whereas the financial support dimension came in last. The results also demonstrated that there was no statistically significant difference at the level of ( $\alpha \leq 0.05)$ in students' perceptions of the role of business incubators in economic development and creativity in Jordanian universities in terms of gender. In contrast, there was a statistically significant difference according to the faculty variable in favor of scientific faculties.

Keywords: Business Incubators, Economic Development, Creativity

\section{Introduction}

The modern world is characterized by openness, competition, and dynamism. Within this rapidly evolving global climate, the best way to achieve optimum outcomes is primarily through investment. This investment should ideally be within the field of scientific research and specifically within the field of human capital.

Human capital is best described as a resource that encompasses creativity and innovation, whilst facilitating modern economic growth and development. Human capital requires nurturing to improve qualifications, skills, and creativity. Academic qualification is insufficient to graduate labor market candidates and consequently, academic inadequacy has been identified as a challenging issue. In other words, there is an inadequacy in preparing human resources. More specifically, achieving economic 
development has become more challenging because universities are producing a large number of graduates, who ultimately end up jobless in developing countries like Jordan. Therefore, governments, worldwide, are unable to meet the overwhelming requirements of the labor market. This challenge has led universities to provide training to students, aimed at becoming more creative and encouraging them to establish their own business while they are still studying.

This is where the creation of 'Business Incubators within universities is vital, as they enable students to become self-sustained. These incubators encourage the younger generation to apply their knowledge learned in school to the outside world, thus helping to rationalize the investment of the human factor. In addition, they encourage students to strengthen work with the idea and principle of self-employment. Consequently, business incubators are a method of development through their ability to provide jobs and diversify the national economic system. This concept of incubating ideas and creativity provides an integrated framework of places, equipment, and facilities, which helps entrepreneurs in their enterprise development. Further, these pioneers will be introduced to the usual risks associated with the work environment and therefore, will be provided with better opportunities for success through a legal entity (Buresh \& Shehaib, 2019).

In providing mediators to help students transfer knowledge from the academic field to business activities, incubators contribute to supporting young university entrepreneurs. The incubator supports ideas and offers evaluation of their application at the same time, while transforming them into entrepreneurial projects of 'Added Value' within the local market. Therefore, business incubators not only encourage students, but they also provide an invaluable gateway that creates conducive conditions towards successful entrepreneurship.

According to Al-Wadi (2010), business incubators act as an effective tool in the process of economic development within developing countries. This will undoubtedly have a positive effect on the development of small and medium firms in these countries. Business incubators can play a significant role in entrepreneurial ideas and projects, especially in the areas of Economic development, as with creative and innovative methods, and encouragement, new innovative products are created. Present-day production is characterized by intense competition and increased progress, making the competition fierce among entrepreneurs. In acknowledging their contribution, this study aimed to understand more and investigate "The Role of Business Incubators in economic development and creativity at Jordanian Universities".

The problem of the study stemmed from the tremendous progress and development in the economic, social, and political fields have created more challenges within the labor market. Statistics have shown that the academic output from universities has been unable to meet the requirements of the labor market, which has led to a growing number of unemployed young people in the job market. This problem persists among the younger generation and has become the basis for developing the idea of incubators, particularly within university campuses.

Presently, the incubator is being adopted as a tool for economic development. Many countries have managed to resolve the issue of youth unemployment among university graduates. The introduction of government funding programs' that help young people to come up with productive businesses has provided them with a stable income. Incidentally, the field matters for creativity and development because after a period of work within these programs, it was realized that the failure rate of projects managed by young people is very high as a result of mistakes due mostly to lack of experience and weak planning abilities, as well as weak oversight.

Many countries partake in reviews of their education and training systems to install new dimensions that aim to spark the interest of students and develop their attitudes towards leadership and creativity while also directing them towards establishing innovative entrepreneurial projects. This all helps to provide an economic environment conducive to the application of their entrepreneurial work through Business Incubators.

According to the significance of the necessity of this approach for young people, much attention is directed to the business incubators that support creativity and innovation, business ideas, their development, and their effects on economic development. It plays a role in adopting innovative 
business ideas and projects to provide economic opportunities for young people.

The purpose of this study is to understand the perspective of students from Mutah University regarding the role of business incubators in economic development and creativity. The research questions are as follows:

1. What is the role of business incubators in economic development and creativity in Jordanian universities from Mutah University students' point of view?

2. Are there statistically significant differences of $(\alpha \leq 0.05)$ in the students' perceptions of the role of business incubators in economic development and creativity in Jordanian universities, which may be attributed to the different faculties they attend or to gender?

With respect to the significance of the study, it is clear that due to the impact that economic and social transformations have on economic institutions, particularly small startups and medium enterprises, business incubators are one of the most important factors that provide diversity in the development of these institutions and entrepreneurial projects. Consequently, the importance of this study lies in understanding the role of business incubators in economic development and creativity. To obtain reliable results, we must first know and understand the theoretical and practical importance of the study, which is explained below.

Secondly, the theoretical importance of the study lies in the fact that there is limited Arabic research that addresses the topic of business incubators, and their role in the development of economics and creativity. There is also limited information on the enhancement of the concepts of leadership, with a focus on reducing unemployment rates and achieving sustainable development.

This study is linked to theoretical literature that contributes to new knowledge of the role of business incubators in economic development and creativity. This is particularly relevant in our Jordanian Universities in directing students towards leadership as a gap in the literature was observed from the previous studies. Our theoretical study will cover that gap based on the importance of leadership and its subsequent orientation. Incidentally, there are also limited published studies on this topic. Additionally, the study results will help decision-makers to identify the strengths and weaknesses of business incubators and their role in economic development and creativity.

Thirdly, the significance of this study lies in the choice of the society in which it is performed, in this case Jordanian universities. In this society, creativity, economic and social developments are encouraged, while intellectual, physical activity, and creativity are inherently connected with young people and their spirit full of desire to achieve the best. The study focuses on some critical topics including business incubators, economic development, and creativity. The results and recommendations clearly define and depict the advantages of this study.

The objectives of the study were:

1. Highlighting the role of business incubators in economic development and creativity in Jordanian universities for students at Mutah University.

2. Revealing the diversity in students' assessments about the role of business incubators in economic development and creativity in Jordanian universities among different faculties and genders.

The following are the important working definitions of the study elements:

$>$ Business Incubators: an integrated work system that provides all the necessary means to increase the success rate of small projects by providing a place equipped with all the capabilities, and the incubator works with the help of specialized management (Alnakhala, 2012).

$>$ Working definition: an organization works to provide an appropriate environment for entrepreneurs while directing them towards leadership, creativity, and innovation to achieve economic development and creativity for university youths. The system provides all forms of consulting, as well as administrative and technical facilities and tools to help entrepreneurs to develop their business ideas and turn them into Business Projects.

$>$ Economic Development: the process of bringing about a set of radical changes in a particular society to provide that community with the ability to continuously develop itself at a rate that 
guarantees an increased improvement in the quality of life for all of its members.

More specifically, it helps in increasing the ability of the community to respond to the basic requirements and needs of its members. These needs are further met through the continuous exploitation of available economic resources, and the proper distribution of the return on that exploitation (Waradam, 2003).

$>$ Working definition: it involves making changes within a particular society through business incubators offering entrepreneurs business ideas through the mobilization of primary resources and labor tools necessary for production, and employing qualified, productive and qualified labor.

$>$ Creativity: the process of making new creations with noticeable, added value for an individual, group, facility, industry, or society. Therefore, creativity is the creation of meaningful value.

$>$ Working definition: the extent of the project's ownership of an innovative idea. It is the ability to modify the product per the desire of the customer.

With regard to the limitation study, the current study has the following limitations:

Geographical determinants: the current study was limited to university business incubators only from Mutah University.

Time limitations: it was conducted during the second semester of 2019-2020.

Human determinants: restricted only to students enrolled in business incubators at Mutah University.

Objective determinants: limited to the topics of business incubators, economic development, and creativity.

\section{Theoretical Framework}

Business incubators have significant importance in protecting business ideas. Implementation of ideas at the early stages requires special support and protection, which enables them later to move to an external labor market. Business incubators are a development program that helps in diversifying economic activity and creating job opportunities while reducing investment risks for business ideas and small businesses.

Incubators play a fundamental role in developing creativity and innovation, which in turn helps to sustain the success of businesses while keeping pace with the growing competition in a dynamic environment, in terms of unprecedented achievements. Business incubators are one of the most innovative systems, because of their success in accelerating the implementation of economic development programs. Business incubators were established primarily to deal with the high rate of failure and the collapse of new projects and SMEs (Small and Medium-sized Enterprises), in the early years of their establishment.

Additionally, business incubators and entrepreneurial centers provide a practical environment that stimulates the engagement of entrepreneurs and their ideas and transforms these ideas into entrepreneurial projects. It is a substantial and complementary addition to the path of cultural change in higher education institutions and thus, governments and universities coordinate with companies to create an environment that stimulates the concept. An economy based on applied knowledge can be termed a business incubator if it accepts entrepreneurs and their creativity, innovations, and capabilities while directing them towards a path that matches their qualities and capabilities. It is aimed at the entrepreneurial crucible, such that it helps in achieving the concept of competitiveness and contributes mainly to the reduction of the unemployment gap (Al-Fawaz, 2014).

\subsection{Business Incubators}

The inception of business incubators began at a manufacturing center known as Batavia in 1959 in the State of New York, in the United States of America. During this time, a family converted the headquarters of their company into units that were rented to individuals who wanted to set up a 
project. The units came with a provision for advice and consultation and the idea witnessed great success, all while being located near banks, shopping areas, and restaurants, which gave rise to the concept that would later become known as an Incubator.

Since 1959, thousands of small institutions have emerged in the center that is still running to date, in an area now known as the "Batavia Industrial Center". It is important to note that this attempt to establish incubators did not systematically follow through until the early eighties, specifically the year 1984. During this time, the Small Enterprise Authority set a program to develop and establish several incubators, but the idea did not work in the United States. There are only 20 incubators whose number rose significantly, one in particular known as the National Association for Business Incubators, which was established in 1985 by American industrialists. This was a private institution aimed at stimulating and regulating the incubator industry, and towards the end of 1997, the number of incubators in the United States had reached 550, with a rapidly increased rate of about an incubator a week towards the end of 1986 (Heikal, 2003).

Business incubators entered the market and endeavored to create new events capable of supporting and nurturing inventions, applying research and creativity, transforming them into companies while raising their chances of success. The idea of incubators came from the incubators used for infants when they are born prematurely, whereby the child is placed inside for a period to overcome the difficulties surrounding them. The Incubator helped create a healthy, livable environment for babies and they could leave the incubator when practitioners were sure they would be able to lead a normal life among others.

A Business Incubator is an integrated framework of place, equipment, services, facilities, support mechanisms, advice, and organization. It is dedicated to assisting entrepreneurs in managing and developing new facilities, be they in production, services, or specializing in research and development. They also support these facilities for a limited period. Therefore, they will take on the usual risks while providing these facilities with greater opportunities for success, through a legal entity established for that purpose (Buresh \& Shehaib, 2019).

Business incubators are also known as integrated systems that carry each project from the beginning, as if it were a newborn needing tender loving care and comprehensive attention, to protect it from any underlying risks. Gradually, it will, of course, push it to become strong, capable of development and self-reliance, and equipped with the necessary elements for continuity and success (Shalaby, 2001).

Business incubators consist of services, facilities, support, and consultation that are provided for a specific period. These institutions are legal entities, with expertise and working relationships for entrepreneurs who need to establish their small institutions while reducing the burdens and start-up costs of their projects (Meraj, 2004).

According to the National Association of Business Incubators, business incubators can be defined as bodies that aim to help innovative institutions emerge and provide new businesspersons with the necessary means through support, expertise, places, and financial support to overcome business burdens including those experienced in the stages of launch and establishment. These systems also provide marketing and publishing services for the products of these institutions (Lavrow \& Sample, 2000).

The integration of the idea of business incubators has been embodied globally, to create an appropriate work environment for small investors, innovators, inventors, and universities. This is possible because incubators create realistic working conditions that aid them to inch towards the business community based on the business philosophy so that their projects will realize success while bringing about creativity in economic projects and managing them accordingly (Al-Wadi, 2010).

Business incubators are the home of entrepreneurs and other stakeholders, like parents, who pay attention to their entrepreneurial children and provide them with services, facilities, tools, and guidance to support their projects while giving them their independence. Work opportunities are created for themselves and others, which helps to reduce unemployment through the creation of muchneeded products and services in the market. 


\subsection{The Importance of Business Incubators}

The importance of business incubators is unquestionable, according to Al-Sawsani and Al-Duwaibi (2003); incubators are a vital stepping-stone to provide investments in areas that are feasible for the national economy. These include technology, small industries, support, and information project incubators as well as others. Taking into account the results of scientific research, business incubators highlight innovations and creativity in the form of projects that make it convertible into production (Al-Sawsani \& Al-Duwaibi, 2003). Through the provision of adequate climates, the correct capabilities and requirements for starting small projects are enhanced.

Business incubators aim to establish and support small or medium production or service projects that are dependent on the application of appropriate technology such as modern innovations, whilst simultaneously providing scientific advice and feasibility studies for emerging small and medium enterprises (Al-Sawsani \& Al-Duwaibi, 2003). They connect emerging and innovative projects with productive sectors, market movement, and requirements.

Generations of qualified business owners support business incubators through the establishment of business rewards, which in turn contribute to the development of production and the creation of job opportunities, which lead to advancement of the economy (Al-Sawsani \& Al-Duwaibi, 2003). Small and medium enterprises help to resolve the administrative, financial, technical, and marketing difficulties that usually face the establishment stage. These incubators also provide support and assistance to small and medium enterprises, helping them to achieve high growth rates and quality. This creates a conducive environment for economic and social development for developing small and medium enterprises of all kinds. With the focus on technological and industrial enterprises the provision of development and growth, including technical, financial, and advisory support, the project is linked to the market (Al-Sawsani \& Al-Duwaibi, 2003).

\subsection{Types of Business Incubators}

According to Al-Shabrawy (2005), there are several types of business incubators, including general business incubators, specialized business incubators, and university business incubators.

General business incubators are incubators that facilitate small and medium business organizations. These organizations are diverse and include multiple disciplines, including sectors of production, industry, and services, but they do not take technological shortcomings into account (AlShabrawy, 2005). Instead, the incubators focus on attracting agricultural business projects or light engineering industry projects that have distinct craftsmanship requirements for regional markets.

Specialized business incubators are incubators that focus particularly on the development of economic aspects of the region in which they are located. This development is achieved through industrial restructuring and support for specific industries (Al-Shabrawy, 2005) though the creation of jobs within targeted specializations and for specific categories of job seekers. The specialized business incubator aims to attract specific investments (Al-Shabrawy, 2005).

Lastly, University Business Incubators are finance-related activities, which are aimed at managing and marketing inventions and innovations. They are also responsible for marketing new research in the industry (Al-Shabrawy, 2005). Also, a few of these business incubators fulfill the role of a technological incubator without walls, which provides consultations and support for new projects. These incubators are launched directly from the university and they research specifically for markets, business people, and financing bodies.

\subsection{Business Incubator Goals}

There is a general agreement that business incubators are a tool for economic development and they do help to strengthen local economies. Small businesses remain in business incubators with a survival rate of $90 \%$. This is a considerably high and attractive rate for the start of entrepreneurial projects (Al- 
Mubaraki et al., 2010). Business incubators operating within the scope of economic development and creativity strive to achieve crucial goals. These goals involve the development of ideas and providing suitable environments, which allow for the growth of these ideas, empowering entrepreneurs, and providing continuous monitoring of entrepreneurial projects (Khalil \& Nour El-Din, 2006).

Business incubators seek to develop innovative ideas that in turn will contribute to finding new projects or developing and expanding upon existing projects. The business incubator will enable and empower entrepreneurs to embody their ideas in the form of products or services (Khalil \& Nour ElDin, 2006). They seek to provide an environment that promotes entrepreneurial ideas of small and medium enterprises as well as attracting national workers and encouraging the development of these workers' skill sets (Khalil \& Nour El-Din, 2006). Through constant encouragement, business incubators encourage the creation of promising economic projects, whilst connecting small and medium enterprises with the productive sectors in the market. Through the provision of support, adequate facilities, constant assistance and sound advice, they make use of results from scientific research and innovations in the form of projects convertible into products (Khalil \& Nour El-Din, 2006). They also provide continuous monitoring of the work and progress of small and medium enterprises while being able to compare the progress to the achievement of predetermined goals (Khalil \& Nour El-Din, 2006).

\subsection{Criteria for Selecting Entrepreneurial Projects}

There is a set of criteria to be met before entrepreneurial projects gain acceptance into Business Incubators. These standards can be summarized as new and innovative ideas and those that will develop quickly, within three years. Acceptance must be based on technological innovations and initiatives; the business needs to produce high-quality products with permanent markets, as well as homogeneity, interdependence, and be able to complement existing, incubated institutions.

Finally, yet importantly, it should contribute to the rehabilitation of administrative frameworks and the development of technical skills, be realistic, and the strategic or company plan must be viable enough to attain funding (Kharraz, 2012).

\subsection{Stages of Incubating Projects Enrolled in the Incubator}

Projects pass through several stages before Incubation and the most pertinent of these are (Sherif \& Bou Nawala, 2012):

Firstly, the study, preliminary discussion, and planning stage: during this stage, through personal interviews between the incubator administration and the applicants for their projects, the seriousness of the idea or project owner is confirmed. The selection criteria apply to the beneficiaries and their projects, the ability of the proposed work team to manage the projects, and the quality and nature of services required by the project from the incubator. The incubator thus provides the marketing strategy and plans that ensure the product's ability to enter the market and plans for the project's expansion.

Secondly, the stage of project planning: taking into consideration the results obtained during the preparation stage, the project plan is created factoring in its feasibility as well as technical and economic aspects.

Thirdly, the stage of establishment, joining, and start of the activity: during this stage, the project is established and contracted with an incubator and a place or site is allocated according to the type of its activity and size.

Fourthly, the project's growth and development stage: at this stage, the performance of the institutions operating inside the incubator is monitored and assistance is given to help them achieve high growth rates through aid and advice, from specialized technical bodies managing the incubator. These bodies also facilitate participation in seminars, workshops, and training courses that take place inside the incubator in cooperation with the institution concerned.

Finally, the graduation phase of the incubator: it is the final stage for projects inside the incubator and is usually a period ranging from 2-3 years after initial acceptance into the incubator. There is a 
specific criterion for graduation, where the project is expected to have achieved a measure of success and growth and finally become able to start its activities outside the incubator with a larger business volume.

\subsection{Conditions for the success of business incubators}

To ensure their success, business incubator projects need to meet certain conditions (Alnakhala, 2012). Through ensuring the support of the community in which business incubators are situated, the stronger the moral support from commercial relations for its region and support of large institutions, universities, and even government support will be. The more the incubator contributes to achieving the goals of the community and contributing to economic development within their region the stronger their support structure will grow (Alnakhala, 2012). To ensure their financial success, the incubator must collect all information on various sources and types of bank or institutional financing, grants, loan funds, and large investors. The incubator can, therefore, be the link between the incubated organization and the funders (Alnakhala, 2012). The selection criteria used to source incubator projects must be defined and clarified to increase the opportunity of attracting an expanse of successful ideas. This may include providing a detailed and specific work plan, exhibiting the ability to grow rapidly, and presenting the project owner to a new invention or idea. The advisor or director of the incubator needs to create a stimulating and positive atmosphere for their incubated institutions with the provision of management skills, marketing, accounting, and the early identification of sudden changes and problems that might occur (Alnakhala, 2012).

Business incubators need to create opportunities to ensure success. They must maintain strong relationships with the main local institutions, have strong links with the press, and have successful managers. The incubator's success requires continuous evaluation of its operations and performance. This is not limited to the incubated institutions only, but also the graduating firms. This evaluated information contributes to the planning and provision of services, as well as marketing itself and attracting projects of promising quality and prosperous growth. Throughout the past two decades, business incubators have proven that they can act as a tool for the revival and development of the economy. This has resulted in increased interest in business incubators at not only a global level but also at Arab and local levels (Alnakhala, 2012).

According to Al-Fawaz (2014), the first local business incubator was established in 2003. It was created to implement the vision of His Majesty King Abdullah II Bin Al Hussein. It works under the supervision of the Higher Council for Technological Sciences to advance the national economy through the facilitation of entrepreneurs to establish their small firms in all fields, with a particular interest in information and communications technology (Al-Fawaz, 2014). This is achieved when ideas are embraced according to their creation of businesses, and support is provided in the form of services in strategic planning, financing, marketing, marketing studies, and the offering of temporary offices and networks (Al-Fawaz, 2014). Additionally, the internet provides an appropriate environment for entrepreneurs to develop their ideas into successful businesses.

Local business incubators were created to achieve economic growth, through the creation of successful companies (Al-Fawaz, 2014). These businesses need to be based on sound administrative and financial foundations; this subsequently creates job opportunities for the people in the region. Business incubators sought pioneers to obtain the necessary financing required. Utilizing their relationship with investment and support agencies, they created channels for linking incubated institutions with large institutions, specializing in various fields of technology and projects locally, regionally as well as globally (Al-Fawaz, 2014). Business incubators consolidated their distinguished relations, who could benefit from their resources and information. These included local and international institutions, research, development centers, chambers of commerce, industry, banks, and other institutions that could benefit (Al-Fawaz, 2014).

Increased financial support was obtained because of the incubator's business and success locally. Simultaneously, business incubators raised the level of science and technology-based activities at the 
national level through inclusive participation in local and international workshops and conferences (Al-Fawaz, 2014).

The economic importance of creativity lies in the fact that all interactions and activities are more dependent than ever on knowledge and intellectual products. The speed of change and development in society today emphasizes that creativity must be given more priority, especially in economic terms, as creativity is significant and highly beneficial.

An innovative individual has confidence in himself and can lead creativity to form continuous development, which helps to be on par with rapid changes. These individuals may become major contributors to the leadership of scientific and technological developments, and their creativity leads to finding innovative methods of producing new products that may also create new organizations. The importance of innovation may not be limited to the level of production and may transition to other areas such as marketing, finance, regulation, etc.

Innovation works to support economic and social development as it finds appropriate and supportive technological methods for development while meeting all consumer needs (Rey \& Fneish, 2007).

\subsection{Business Incubators and Development for Creativity and Innovation}

Business incubators seek to create an appropriate atmosphere for the development of creativity and innovative capabilities, as well as specialized skills by encouraging the spirit of creativity, and innovation.

Changes surrounding business organizations are not limited to the introduction of modern production methods or new products alone. Development in all areas can happen through a series of small and major improvements and additions to the current product or service. The business incubators seek to develop the capacity for imagination and creativity among business organization owners, through a variety of educational programs based on the identification and study of scientific experiments, leading to the development or innovation of an idea. More specifically, business incubators aim to develop the spirit of entrepreneurship while embedding a love of self-employment through the improvement of administrative talents while preparing them to adopt new ideas and prepare for risk.

This all leads to the creation of advanced organizations that can develop a better understanding of the mechanisms of competition in the global market. Incubators seek to organize exhibitions and seminars and provide technical support to attract financiers as a prelude to their communication with the incubated, while also building networks of communication among them to find out what is happening first.

Participating in experiences, while working on complementarity and non-duplication as well as reducing costs is necessary for helping businesses to obtain new technical money. The incubators are linked to each other through communication networks (Buresh \& Shehaib, 2019).

\subsection{University Business Incubators}

The idea behind the inception of university incubators began as a transformative point. It was created and thought of as a strategy to build a bridge that translates the academic role into practical activities. As the student's orientation towards their career is affected, they would thus interact with the surrounding environmental conditions, especially when they are in the stage of forming a career path. This most crucial state is the incubation period within the university and many students would be looking for a model that fits in with their ideas (Fayolle \& Degeorge, 2006).

Perhaps the most important reason behind the establishment of business incubators is the need for the university to support entrepreneurs and owners of innovative ideas, to create a new, sensitive, and renewed role that contributes to economic development.

The university may provide investment and operational opportunities for its final outputs, most 
important of which is scientific research through this type of incubator, aiming to adopt creators and innovators while transforming their ideas and projects from a laboratory model to production and investment. This is accomplished when they provide services, support, and practical assistance to obtain a product that creates added value in the market economy. By accepting creative and distinguished ideas for young men and women, job opportunities for young men and women can be generated, providing investment opportunities for self-development, as well as contributing to making the information-based knowledge society, eliminating the causes of brain drain, and marketing scientific and technical outputs (Turkmani, 2006).

\subsection{Barriers to Business Incubators}

Despite the role that business incubators play in serving projects and individuals, they may face some problems, which may affect their role or limit their effectiveness (Itani, 2004; Barhoum, 2014):

Firstly, the business incubator may not garner all the support it needs from the local community, particularly at the beginning of its establishment, which would also affect the nature of the services provided.

Secondly, the expectations may be too high to the extent of the services that could be obtained from the projects, especially regarding the administrative, financial, and technical aspects. Consequently, there may be many who are disappointed that the incubator did not meet this demand. This could lead to an incubator's ambition level rising unrealistically, while the incubator's financial and human capabilities are limited.

Thirdly, the quality of communications and reactions of the parties targeted by the incubator to facilitate the work of the incubated institution could be affected. Reliability is the dependence of incubated institutions on incubators in various fields.

Many countries have started adopting the idea of business incubators, because of their belief and even certainty that business incubators play a vital role in developmental, economic, and social activities. They represent the mediator who translates scientific achievement and human creativity into serious and productive business projects and creates new job opportunities. The university can be an effective tool in economic and local development through its contribution to the formation and activation of human resources through business incubators, which play a vital role as an effective mediator between university training and the labor market, bringing together industry and technology.

This incubation allows students and graduates to embody creative and innovative ideas as well as a willingness to face the new stage after graduation, and orientation towards the labor market. The private sector governs this area and leaves them subject to new concepts. Therefore, having a foundation for self-employment must be encouraged as economic development depends on this.

\section{Literature Review}

This section examines previous studies of the research topic, starting from the most recent to the oldest.

Buresh and Shehaib's (2019) study aimed to identify the role of business incubators in supporting creative and innovative projects for business organizations and their implications for sustainable development. The study adopted the descriptive-analytical approach. The most prominent results of the study were that business incubators contribute to developing creativity and innovation in large business organizations, in terms of the number of creations and innovations. In this study, business incubators were declared as the most important ways to support creativity and innovations for emerging small and medium-sized entrepreneurial projects that help them to continue and develop their competitive capabilities. It was found that business incubators contribute to the promotion of the national economy and support institutions in activating the economic growth strategy accompanying the increase in employment opportunities.

Another study by Mansouri \& Bou Asida (2019) aimed at identifying the role of business 
incubators as a mechanism to support innovation in small and medium enterprises, as it is one of the important pillars of the sustainability of the success and of these institutions in light of a highly competitive pace and an environment of continuous development and renewal, trying to answer the following questions: "What is the role of Business incubators in support of innovation at the level of Algerian SMEs?" It adopted a descriptive-analytical approach and provided analysis of statistical and applied data. It concluded that Algeria is still lagging in this field despite the interest it has taken in the SME sector and its modest experience regarding business incubators. Nevertheless, providing the appropriate conditions for the establishment of such incubators will greatly assist Algerian SMEs in innovation and growth to compete and continue in the markets, thus contributing to technological development and advancing economic and social development along the lines of several developed and emerging countries.

Amara and Park (2019) had a study that sought to identify business incubators as a prerequisite to supporting creativity and innovation in small and medium enterprises and adopted a descriptiveanalytical approach. The results of the study established that business incubators are an integrated system to support small enterprises and it is appropriate to give those institutions support and these business incubators are one of the modern methods to support innovation and creativity for entrepreneurial projects and small and medium enterprises. Business incubators have a major role in developing the economy. They invest in successful creative ideas and turn them into projects of promising economic growth, and create a competitive advantage for the national organization.

Ammar and Sabiq (2017) had a study aimed at identifying the role of technology business incubators in supporting creativity and innovation in small and medium enterprises. In this study, the scientific method relied upon the use of a descriptive inductive approach and the deductive analytical approach. The most prominent results were that business incubators are gaining great importance in the national economy, in terms of providing employment opportunities and graduating successful organizations capable of performing successfully within the market. This is especially true in light of the challenges that globalization poses to emerging projects, considerably so when it comes to small and medium enterprises, and expansion and diversification of the economic base after investing thousands in successful pilot projects, and turning them into promising economic projects.

Kalakhi and Syed (2016) sought to identify the role of business incubators in economic development concerning the Algerian experience. The descriptive approach was adopted, and the most important results of the study showed that business incubators have an interrelated relationship with the intellectual presentation of the role they play. This particular role is achieving development in the new concept of the changes that the global economy, as well as the new job opportunities, provides to society in creating wealth. It will contribute to the creation of added values that it produces. Meanwhile, the local community and country have given support to the emerging enterprise sector and small and medium enterprises.

Al-Wadi (2010) sought to understand the role of business incubators in economic development "With the Reference to the Jordanian Experience" where the descriptive approach was adopted to measure and evaluate the performance of incubators in Jordan. The study covered projects that graduated from Jordanian business incubators that included 27 projects. The study sample consisted of 18 of those projects chosen randomly. The study tool consisted of a questionnaire and the most prominent results of the study were that the evaluation of projects for incubators in Jordan was average, and while the confidence of projects in the university's role was high, the confidence in the role of culture institutional environment for the development of incubators was weak.

\section{Methodology and Procedures}

This part of the study highlights the research methodology followed in the study. It is based on a literature review covered in the theoretical framework of the study, which provided theoretical and academic engagement and a literature review in the field of interest in the study. The researcher reviews the study method and determines a sample as well as the presentation of the study tools with 
an explanation of how to verify their credibility.

\subsection{Research Methodology}

This study relied on a descriptive analytical approach that includes conducting a desk survey by referring to the sources for building the theoretical framework for the study and a field survey to collect data using questionnaires. It was distributed to a sample of the study population and analyzed statistically to answer the study questions to achieve its objectives and provide recommendations, in the light of its results.

\subsection{The Sample of Study}

The study population consists of all students at 'Mutah University' who enrolled in the entrepreneurship program during the year 2019-2020, and it accounts for 460 students. The sample size of the study was 230 male and female students, who were randomly selected from the study population. The questionnaire was distributed to the participants of the study sample. 208 questionnaires were retrieved from them and all of them were valid for statistical analysis. The collected questionnaires accounted for $90.4 \%$ of the distributed questionnaires to the study sample.

Table 1: The respondents' demographics variables; gender and faculties

\begin{tabular}{|l|l|c|c|}
\hline Variable & Variable Categories & Number & Percentage \\
\hline \multirow{3}{*}{ Gender } & Male & 100 & $48 \%$ \\
\cline { 2 - 4 } & Female & 108 & $52 \%$ \\
\cline { 2 - 4 } & Total & $\mathbf{2 0 8}$ & $\mathbf{1 0 0} \%$ \\
\hline \multirow{3}{*}{ Faculty } & Science & 130 & $67 \%$ \\
\cline { 2 - 4 } & Arts/ Humanities & 78 & $33 \%$ \\
\cline { 2 - 4 } & Total & $\mathbf{2 0 8}$ & $\mathbf{1 0 0} \%$ \\
\hline
\end{tabular}

Table (1) shows $48 \%$ of respondents were males and $52 \%$ were females. Also, $67 \%$ of respondents were attending sciences faculties, while $33 \%$ were attending arts and humanities faculties.

\subsection{Study instrument}

To achieve the study objectives, the questionnaires designed had the following parts:

Part One: it includes the characteristics of the sample of the study accounting for demographic or personal variables; specifically, gender and faculties.

Part Two: it includes paragraphs 1-38 that measure 'the role of business incubators in economic development and creativity in Jordanian universities'. It includes four dimensions; these are:

Paragraphs (1-10) measure the training and consulting dimension.

Paragraphs (11-22) measure the technical support dimension and evaluate performance.

Paragraphs (23-33) measure the administrative and office services dimension.

Paragraphs (33-38) measure the dimension of financial support and financing.

The weights of the resolution paragraphs were adopted according to the 'Likert Scale' as follows: (always: 5 degrees), (frequently: 4 degrees), (sometimes: 3 degrees), (rarely: two degrees), (never: one degree).

\subsection{Questionnaire validation}

The questionnaire was validated by the authentication of the arbitrators. The draft of the questionnaire was seen by a group of ten arbitrators. Arbitrators are experienced and specialized in the field of 
business administration and economics and they were asked to express their opinion on the clarity of the paragraphs, their connection to the field and the extent of their suitability for measurement and clarity of meaning. They were completed by adhering to the comments of the arbitrators. Any paragraphs identified by arbitrators as unsuitable were excluded. Therefore, the final questionnaire consisted of 38 paragraphs.

\subsection{Questionnaire reliability}

The correlation coefficients of the paragraphs with the dimensions that fall under it were calculated to verify the internal consistency of the questionnaire, as well as the coefficient of correlation of paragraphs with the overall degree of the scale. The correlation coefficients ranged from 0.61 to 0.82 , with all of them having a significance level at $(\alpha \leq 0.05)$. These results enhance the reliability of the questionnaire.

The Internal consistency coefficient of the questionnaire extracted, based on the 'Cronbach's $(\alpha)$ ' coefficient for the questionnaire and its dimensions.

Table 2: Cronbach's $(\alpha)$ coefficient for the questionnaire and its dimensions

\begin{tabular}{|l|c|}
\hline Dimension & Cronbach's $(\boldsymbol{\alpha})$ \\
\hline Training and consulting & 0.87 \\
\hline Technical support and performance evaluation & 0.86 \\
\hline Administrative and office services & 0.90 \\
\hline Financial support and financing & 0.89 \\
\hline Total & 0.93 \\
\hline
\end{tabular}

Table (2) shows Cronbach's $(\alpha)$ coefficients for the questionnaire and its dimensions, and they ranged from 0.86 to 0.90 ; Cronbach's $(\alpha)$ coefficients for the overall questionnaire is (o.93), and such values were considered acceptable for the study.

\subsection{Study Procedures}

After verifying the validity and reliability of the questionnaire and its final version, the following procedures followed:

1) The questionnaire was distributed to the study sample. During the distribution answers were given to respondents' comments and inquiries as well as to make them aware of the importance of the study and to answer each objective of the study tools. The questionnaires were received in the same way in which they were distributed.

2) The data collected were entered into 'Statistical Package for Social Sciences' in preparation for analysis and extracting the results of the study.

3) Criteria were adopted to further elucidate the meaning of the mean in the responses of the individuals in the study sample: Low importance - Less than 2.33; Medium importance Greater or equal to 2.33 and less or equal to 3.66; High importance - greater than 3.66.

\subsection{Study Variables}

The current study included two types of variable:

Independent variable: represented in the current study as either gender or faculty.

Dependent variable: represented by 'the role of business incubators in economic development and creativity in Jordanian universities'. This is measured by the responses of the respondents to the questionnaire. 


\subsection{Statistical analysis}

To answer the study questions, descriptive and analytical statistical methods were used, employing the Statistical Package for Social Sciences (SPSS, version 19) as follows:

- Descriptive statistics measurements to describe the characteristics of the study sample in percentages, and to describe the levels of 'the role of business incubators in economic development and creativity in Jordanian universities'.

- 'Two-way Analysis of Variance Test' (Two Way ANOVA Test) to detect the significance of differences in the level of 'the role of business incubators in economic development and creativity in Jordanian universities' from the viewpoint of students according to the gender variable and the faculty.

- Pearson correlation coefficient and Cronbach $(\alpha)$ used to verify the reliability of the questionnaire.

\section{Results and Discussions}

This section includes a detailed presentation of the results of the study concerning the questions posed, as well as a discussion of the results and their interpretation.

5.1 Question One: "What is the role of business incubators in economic development and creativity in Jordanian universities from the viewpoint of students at 'Mutah University'?"

In response to question one, the mean and standard deviations were calculated for students' perceptions of the reality of the role of business incubators in economic development and creativity in Jordanian universities at the level of each dimension, as shown in Table (3).

Table 3: Means and standard deviations of students' perceptions of the role of business incubators in economic development and creativity.

\begin{tabular}{|c|l|c|c|c|}
\hline Rank & Dimensions & Mean & SD & Level \\
\hline 1 & Training and Consulting & 3.88 & 0.55 & High \\
\hline 3 & Technical Support and Performance Evaluation & 3.59 & 0.97 & Average \\
\hline 2 & Administrative and Office Services & 3.80 & 0.68 & High \\
\hline 4 & Financial Support and Financing & 3.46 & 0.60 & Average \\
\hline & TOTAL & 3.68 & 0.59 & High \\
\hline
\end{tabular}

Table (3) shows that the respondents perceive business incubators to have high importance in economic development and creativity in Jordanian universities, with a mean of (3.68) and a standard deviation (0.59). Furthermore, the dimension of the training and consulting has a mean of (3.88) and a standard deviation of (0.55), reflecting also a level of high importance according to the criteria applied. The dimension of administrative and office services came in second with a mean of (3.80) and a standard deviation of (o.68), and therefore a level of high importance also. The technical support and performance evaluation came in third rank with a mean of (3.59) and a standard deviation of (0.97), highlighting student perceive them to have a medium level of importance in economic development and creativity in Jordanian universities. Finally, financial support and financing came in the last place with a mean of (3.46) and a standard deviation of (o.6o), reflecting also a medium level of importance. 


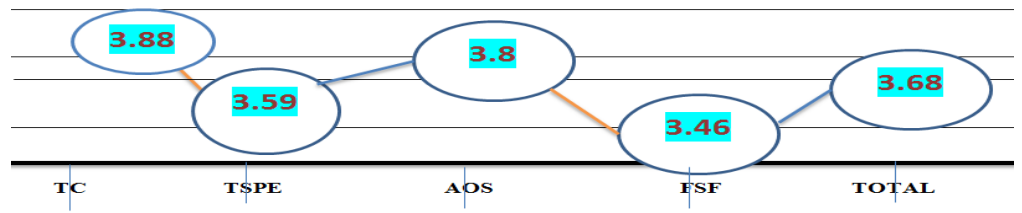

Where,

TC refers to "Training and Consulting".

TSPE refers to "Technical Support and Performance Evaluation".

AOS refers to "Administrative and Office Services".

FSF refers to "Financial Support and Financing".

Figure (1): The difference in students' perceptions of 'the role of business incubators in economic development and creativity' according to the dimensions:

The students have different perceptions regarding the role of business incubators in economic development and creativity, depending upon different dimensions. This result can be attributed to the fact that the idea of business incubators has gained roots in the Jordanian universities, and that business incubators have started practicing their roles more effectively within universities, and among the student community. It works to translate the pioneering ideas that students put into projects on the ground, and this matter requires the support of business incubators through the provision of training and consultation, as well as technical support and administrative services. It has thus encouraged students to turn to business incubators and present their projects and business ideas. The researcher can also assign 'the role of business incubators in economic development and creativity' to the economic conditions of the country. Additionally, the lack of job opportunities available to undergraduate students made the presence of business incubators a requirement and an urgent necessity to compel students to innovate and create and establish their projects through which they could acquire a source of income while creating job opportunities for others who can engage in similar projects.

The researcher can also attribute the fact that after financial support and funding, the last rank has been obtained between the dimensions, that creative ideas need technical care in the first place. Also, it may be concluded that financial support may not be the basis, as creative ideas can market themselves if they are implemented.

5.2 Second Question: "Are there statistically significant differences at the level of significance $(\alpha \leq 0.05)$ in students' estimates of the role of business incubators in economic development and creativity in Jordanian universities with different faculty/gender?"

Second Response 'Two-way Analysis of Variance Test' (Two Way ANOVA Test) was used to reveal the differences in students' assessments of 'the role of business incubators in economic development and creativity in Jordanian universities' according to the variables of faculty and gender, as shown in Table (4).

Table 4: Variance analysis for the differences in students' perceptions of the role of business incubators in economic development and creativity in Jordanian universities according to the variables of faculty and gender.

\begin{tabular}{|l|c|c|c|c|c|}
\hline Source of Contrast & Sum of Squares & Degrees of Freedom & Average Squares & Value (p) & Significance Level \\
\hline College & 1.559 & 1 & 1.559 & 14.72 & 0.000 * $^{*}$ \\
\hline Gender & 0.0140 & 1 & 0.01400 & 0.1320 & 0.2160 \\
\hline Error & 21.821 & 206 & 0.1059 & & \\
\hline TOTAL & 1681.545 & 208 & & & \\
\hline
\end{tabular}

* Statistically significant at the level $(\alpha \leq 0.05)$ 
Table (4) indicates that there are no statistically significant differences at the level of $(\alpha \leq 0.05)$ in students' perceptions of the role of business incubators in economic development and creativity in Jordanian universities according to the variable of gender. This may be due to the role of business incubators in economic development and creativity in Jordanian universities' targeting male and female students alike. These are all under one educational umbrella, which does not differentiate between males or females through its programs and activities aimed at economic development, and creativity. However, the results show that there are differences attributable to the faculty variable, and when extracting the mean, it appeared that the estimates of students of scientific faculties were (3.76), while estimates of students of art and humanities faculties reached (3.46).

These results indicate that the differences are in favor of scientific faculties, and this result can be attributed to the fact that students of scientific faculties are profoundly more interested in creativity, and that many university courses within these faculties emphasize the preparation of graduation projects, particularly those that are specific to the courses. This issue is pertinent and contributes to the production of creative ideas that can be adopted as pioneer projects through incubators, so their assessments of the role of business incubators in economic development and creativity appeared more in scientific faculties than in other faculties.

\section{Conclusion and Recommendations}

In conclusion, the 'Role of Business Incubators in Economic Development and Creativity in Jordanian Universities' is highly associated with the key factor 'training and consulting' whereas 'financial support' matters the least. Irrelevant of the gender type of the survey participants, the infographic scale showed a significant variation in the data collected against discreet faculties such as Science and Arts/Humanities, which received an overwhelming response in favor of faculty variable 'Science' which was $67 \%$ in contrast to Arts which was $33 \%$.

Despite some limitations - for the study was confined solely to Mutah University and restricted only to students enrolled in business incubators there - the report uncovers various fundamental features that set the threshold for a better national economy of any country. Various studies carried out in the past have also proved the importance of business incubators and endorsed the fact that they play a vital role in establishing projects and serving entrepreneurs, no matter whether individuals or corporates. What cannot be ignored is the crucial aspect that certain barriers can limit the efficacy of business incubators and yet, there are particular conditions that also need to be fulfilled to ensure success. These conditions include paying more attention to the weak areas and thereby, generating more incentives that lead to the creation of advanced organizations as creativity and innovation go hand in hand with business incubators.

In light of the findings of the study, the following recommendations are suggested:

- Enhance financial support for creative projects, especially within the early stages of the project launch.

- Establish systematic mechanisms to support students and urge them to go towards business incubators to showcase their creative projects and ideas.

- Establish the concept of leadership amongst students through training workshops and academic courses, for which trainers or staff will need to be suitably qualified.

\section{References}

Al Wadi, M. 2010. The role of business incubators in economic development "concerning the Jordanian experience." Journal of economic and administrative research, (7), 1-23.

Al-Fawaz, I. 2014. Role of Business Incubators in Students Orientation toward Entrepreneurship in Jordanian Universities. Master Thesis, Yarmouk University, Jordan.

Al-Mubaraki, H. M., \& Busler, M. 2010. Business incubators: Findings from a worldwide survey, and guidance for the GCC states. Global Business Review, 11(1), 1-20. 
Alnakhala, M. 2012. The reality of business incubators and their role in supporting small projects with youth in the Gaza Strip. The Youth \& Development in Palestine conference, the Islamic University, Palestine, April 24-25, 2012.

Al-Sawsani, R. \& Al-Duwaibi, A. 2003. Business incubators and micro-enterprises. Benghazi: National Library of Books. Libya.

Al-Shabrawy, A. 2005. Business Incubators: Initial Concepts and International Experiences. Rabat: publications of the Islamic Educational, Scientific, and Cultural Organization.

Amara, S. \& Park, N. 2019. Business incubators ... An essential requirement to support creativity and innovation in small and medium-sized enterprises - an experience of Algeria incubators and Austin Technology Incubator in the United States as a model. El Acil for Economic and Administrative Research, 3(1), 108-122.

Ammar, Z. \& Sabiq, N. 2017. The role of technology business incubators in supporting creativity and innovation in small and medium enterprises. Industrial Economics Magazine, 12(1), 348-363.

Barhoum, B. 2014. The role of business incubators and technology in solving the problem of unemployment for entrepreneurs Gaza Strip. Master Thesis, Islamic University, Gaza, Palestine.

Buresh, A. \& Shehaib, S. 2019. The role of business incubators experiences in supporting creative and innovative projects of business organizations and their implications for sustainable development (experiences and approaches). Finance and Business Economy Review, 3 (2), 94-115.

Fayolle, A., \& Degeorge, J. M. 2006. Attitudes, intentions, and behavior: New approaches to evaluating entrepreneurship education. International entrepreneurship education. Issues and newness, 74-89.

Heikal, M. 2003. Small project management skills. Cairo: The Arab Nile Group.

Itani, R. 2004. Business Incubators as a Mechanism to Support Small Business Enterprises in the Globalization Era. Rosicada Magazine- Skikda University, Algeria, 2, 63-64.

Kalakhi, L. \& Syed, H. 2016. The role of business incubators in economic development, concerning the Algerian experience. Journal of Economic Integration - Algeria, 9, 217-243.

Khalil, A. \& Nour El-Din, H. 2006. The role of business incubators in supporting the creativity of small institutions in Arab countries. The international forum, the requirements for qualifying small and medium enterprises in the Arab countries, Hassiba Ben Bouali University, Chlef, Algeria, April 17-18, 2006.

Kharraz, H. 2012. The role of business incubators in the establishment and sustainability of Algerian small and medium-sized enterprises - a case study of the Guardian Incubator. Master thesis, Kassadi University, Mirbah Ouargla.

Lavrow, M., \& Sample, S. 20oo. Business Incubation: Trend or Fad?-Incubating the Start-up Company to the Venture Capital Stage: Theory and Practice. University of Ottawa EMBA Report.

Mansouri, M. \& Bouassida, R. 2019. Business incubators as a mechanism to support innovation in Algerian SMEs. Journal of Business and Finance - University of the Martyr Hama Al-Akhdar in the Wadi, 4 (1), $215-230$.

Meraj, H. 2004. Business Incubators Support Mechanisms for Small and Medium Enterprises, Intervention in the First National Forum; Investment Opportunity in the State of Ghardaia and the Role of Small and Medium Enterprises - Reality and Challenges, The National Institute of Commerce, Mellili, Ghardaia, March 2-3, 2004.

Rey, M. \& Fneish, A. 2007. The role of innovation in enhancing the competitiveness of the economic establishment, paper presented to the international symposium on resistance and creativity in developing countries, University Center Khamis Miliana, Algeria, November.

Shalaby, N. M. 2001. How can Saudi Arabia benefit from Business Incubators and Technology Parks? Saudi Commerce and economic review magazine, 88(1), 29-36.

Sherif, R. \& Bou Nawala, R. 2012. Business incubators as a mechanism to accompany small enterprises - a proposed model in the field of information technology. Strategy for Organizing and Accompanying Small and Medium Enterprises in Algeria international conference, Kassadi University, Mirbah Ouargla, Algeria, April 18-19, 2012.

Turkmani, A. 20o6. The Role of Intermediate and Supporting Institutions. The National Conference for Scientific Research and Technological Development, Damascus, Syria, May 24-26, 2006.

Waradam, B. 2003. The world is not for sale: the risks of globalization to sustainable development. Al'ahliah for publication and distribution, Amman, Jordan. 